\title{
Palaeohistology and palaeopathology of an Aeolosaurini (Sauropoda: Titanosauria) from Morro do Cambambe (Upper Cretaceous, Brazil)
}

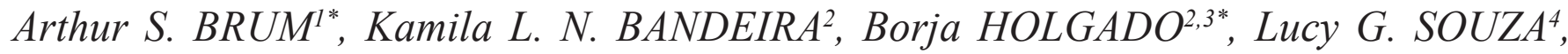 \\ Rodrigo V. PEGAS $S^{5}$, Juliana M. SAYÃO ${ }^{1,2}$, Diogenes A. CAMPOS ${ }^{6} \&$ Alexander W. A. \\ KELLNER ${ }^{2}$
}

\footnotetext{
${ }^{1}$ Laboratório de Paleobiologia e Paleogeografia Antártica, Departamento de Geologia e Paleontologia, Museu NacionalUniversidade Federal do Rio de Janeiro, Quinta da Boa Vista, São Cristóvão, 20940-040 Rio de Janeiro, RJ, Brazil, arthursbc@yahoo.com.br; jmsayao@gmail.com

${ }^{2}$ Laboratório de Sistemática e Tafonomia de Vertebrados Fósseis, Departmento de Geologia e Paleontologia, Museu Nacional/ Universidade Federal do Rio de Janeiro, Quinta da Boa Vista s/n, São Cristóvão, 20940-040 Rio de Janeiro, RJ, Brazil, kamilabandeira@yahoo.com.br, borja.holgado@mn.ufrj.br, kellner@mn.ufrj.br

${ }^{3}$ Institut Català de Paleontologia 'Miquel Crusafont', C/ de les Columnes, Universitat Autònoma de Barcelona, E-08193 Cerdanyola del Vallès, Barcelona, Catalonia, Spain.

${ }^{4}$ Museu da Amazônia, Av. Margarita, 6305, Jorge Teixeira, 69088-265 Manaus, AM, Brazil, souzalucyg@gmail.com

${ }^{5}$ Laboratório de Paleontologia de Vertebrados e Comportamento Animal, Universidade Federal do ABC, Alameda da Universidade s/n, Anchieta, 09606-045 São Bernardo do Campo, SP, Brazil, rodrigo.pegas@hotmail.com

${ }^{6}$ Museu de Ciências da Terra, Serviço Geológico do Brasil - CPRM, Avenida Pasteur 404, Urca, 22290-255 Rio de Janeiro, RJ, Brazil, diogenes.campos@cprm.gov.br
}

*Corresponding author

Brum, A.S., Bandeira, K.L.N., Holgado, B., Souza, L.G., Pêgas, R.V., Sayão, J.M., Campos, D.A. \& Kellner, A.W.A. 2021. Palaeohistology and palaeopathology of an Aeolosaurini (Sauropoda: Titanosauria) from Morro do Cambambe (Upper Cretaceous, Brazil). [Paleohistología y paleopatología de un Aelosaurini (Sauropoda: Titanosauria) de Morro do Cambambe (Cretácico Superior, Brasil)]. Spanish Journal of Palaeontology, 36 (1), 1-18.

Manuscript received 17 December 2019

https://doi.org/10.7203/sjp.36.1.20305

Manuscript accepted 19 August 2020

(C) The Authors (2021)

\section{ABSTRACT}

A recent publication of fossil bones of titanosaurs assigned to Aeolosaurini from the Morro do Cambambe site (Mato Grosso state, Brazil, Upper Cretaceous) reported anomalous growth in some of them. Here, we present osteohistological sections of elements to understand not only the microstructure and growth of such bones, but also the nature of those anomalies. Among them, we selected one cervical and one mediumposterior dorsal rib, and a haemal arch. The primary bone of all specimens consisted of a variation of the fibrolamellar complex, with the inner cortex being rich in woven bone

\section{RESUMEN}

En una reciente publicación de los huesos fósiles de titanosaurios asignados al clado Aeolosaurini provenientes del yacimiento de Morro do Cambambe (estado de Mato Grosso, Brasil, Cretácico Superior), se reconocieron anormalidades en el crecimiento de algunos de ellos. En el presente trabajo presentamos cortes osteohistológicos de elementos para entender no sólo la microestructura y crecimiento de los mismos, sino también la naturaleza de aquellas anomalías. Entre ellos, seleccionamos una costilla cervical y una costilla dorsal media posterior, así como un arco hemal. El hueso 
with dispersed longitudinal canals, while the outer cortex was parallel-fibred with rows of longitudinal canals, interlayered by Lines of Arrested Growth. We identified a maximum of two Lines of Arrested Growth in the cervical rib and haemal arch, and four in the dorsal rib. The haemal arch shows an External Fundamental System in most sections. The advanced remodelling and variation of the fibrolamellar bone in the cortex suggests that all the specimens represent individuals that reached sexual maturity. However, the haemal arch was distinct due to the wide distribution of External Fundamental System. Based on the microstructure, we identified a subadult semaphoront, and probably an adult. The dorsal rib exhibited periosteal and endosteal outgrowth. Such microstructure was assigned to a reactive bone due to an intra-thoracic infection (a pneumonia, probably related to a tuberculosis), which is the first report in a non-avian dinosaur. The microstructure resembles the medullary bone recovered in dinosaurs, which suggests that further studies of medullary bone in thoracic bones should also regard the pathological cases.

Keywords: Pneumonia, palaeohistology, palaeopathology, Titanosauria, Upper Cretaceous, Brazil. primario de todos los especímenes comprendía una variación del complejo fibrolamelar, siendo la corteza interna rica en tejido reticular óseo con canales longitudinales dispersos, mientras que la corteza externa tenía fibras paralelas con hileras de canales longitudinales, intercaladas por líneas de crecimiento detenido. Identificamos un máximo de dos líneas de crecimiento detenido tanto en la costilla cervical como en el arco hemal, y cuatro en la costilla dorsal. El arco hemal muestra un Sistema Externo Fundamental en la mayoría de las secciones. La remodelación avanzada y la variación del hueso fibrolamelar en la corteza, se sugiere que todas los especímenes alcanzaron la madurez sexual. Sin embargo, el arco hemal fue distinto debido a la amplia distribución de Sistema Externo Fundamental. Con base en la microestructura, identificamos un semaforonte subadulto, y probablemente a un adulto. La costilla dorsal mostró una excrecencia perióstica y endosteal. Dicha microestructura se ha identificado con un hueso reactivo a una infección intratorácica (una neumonía, probablemente relacionada con una tuberculosis), que es el primer informe de un dinosaurio no aviano. La microestructura se asemeja al hueso medular recuperado en los dinosaurios, lo que sugiere que los estudios posteriores del hueso medular en los huesos torácicos también deberían considerar los casos patológicos.

Palabras clave: Neumonía, paleohistología, paleopatología, Titanosauria, Cretácico Superior, Brasil.

\section{INTRODUCTION}

Titanosaurs were a diverse group of Cretaceous sauropod dinosaurs, which was globally distributed and the largest terrestrial animals ever known (Carballido et al., 2017; Calvo \& González Riga, 2019; González Riga et al., 2018, 2019). The titanosaur record from Brazil has increased continuously with the description of new specimens, especially those coming from the Upper Cretaceous Bauru Group, providing data on palaeobiology, palaeobiogeography and the evolution of the group (Bandeira et al., 2016; Brusatte et al., 2017). Thus far, the fossils from the Bauru Group layers of Mato Grosso state are scarce, fragmentary and limited to a few taxa (Franco-Rosas et al., 2004; Bandeira et al., 2019). FrancoRosas et al. (2004) were the first to identify at subgroup titanosaurian level the axial and appendicular remains collected at Morro do Cambambe site. More than a decade later, Bandeira et al. (2019) identified the largest collection of bones in Mato Grosso, also from Morro do Cambambe site, and assigned all of them to distinct Aeolosaurini individuals. Among the fossil bones, an anomalous osseous growth was observed in a dorsal rib, which was inferred as a palaeopathology.
The palaeopathological studies on dinosaurs, especially sauropods, are still scarce in the literature (e.g., Hatcher, 1901; Gilmore, 1936; Rothschild \& Berman, 1991; Tschopp et al., 2016; Gonzalez et al., 2017; Barbosa et al., 2016, 2018, 2019). Although the first reports of bone abnormalities in this clade were made by Hatcher (1901), palaeopathological studies have gained attention with the methodological improvement of palaeohistology and computed tomography in the last decades (e.g., Anné et al., 2015). In this context, palaeohistology provides not only inferences about development and metabolism (Horner et al., 2001; Padian et al., 2001), ecological adaptations (Aureliano et al., 2018), and osteological correlations (Lambertz et al., 2018), but also to clarify the bone response to infections and injuries (e.g., Chinsamy \& Tumarkin-Deratzian, 2009; Cerda et al., 2014).

Here, we present a detailed microstructural description of three axial bones of an Aeolosaurini from Morro do Cambambe (Mato Grosso state; Upper Cretaceous). Our study aimed to make inferences about life history traits and investigated an anomalous osseous growth in the dorsal rib. The analysis of the microstructure of this anomalous bone showed critical data concerning the identification of medullary bone in non-avian dinosaurs. 


\section{GEOLOGICAL SETTINGS}

The Morro do Cambambe site (Fig. 1) is one of best-known fossiliferous spots in Mato Grosso. The geological settings from this site are not well established (for a revision, see Bandeira et al., 2019). Briefly, the strata of Morro do Cambambe were formed under fluviolacustrine conditions, with conglomerates intercalated to medium-grained sandstones (Weska, 2006). More recent works (e.g., Brusatte et al., 2017) correlate the Morro do Cambambe to the Presidente Prudente and Marilia Formations, both from the Upper Cretaceous Bauru Group.

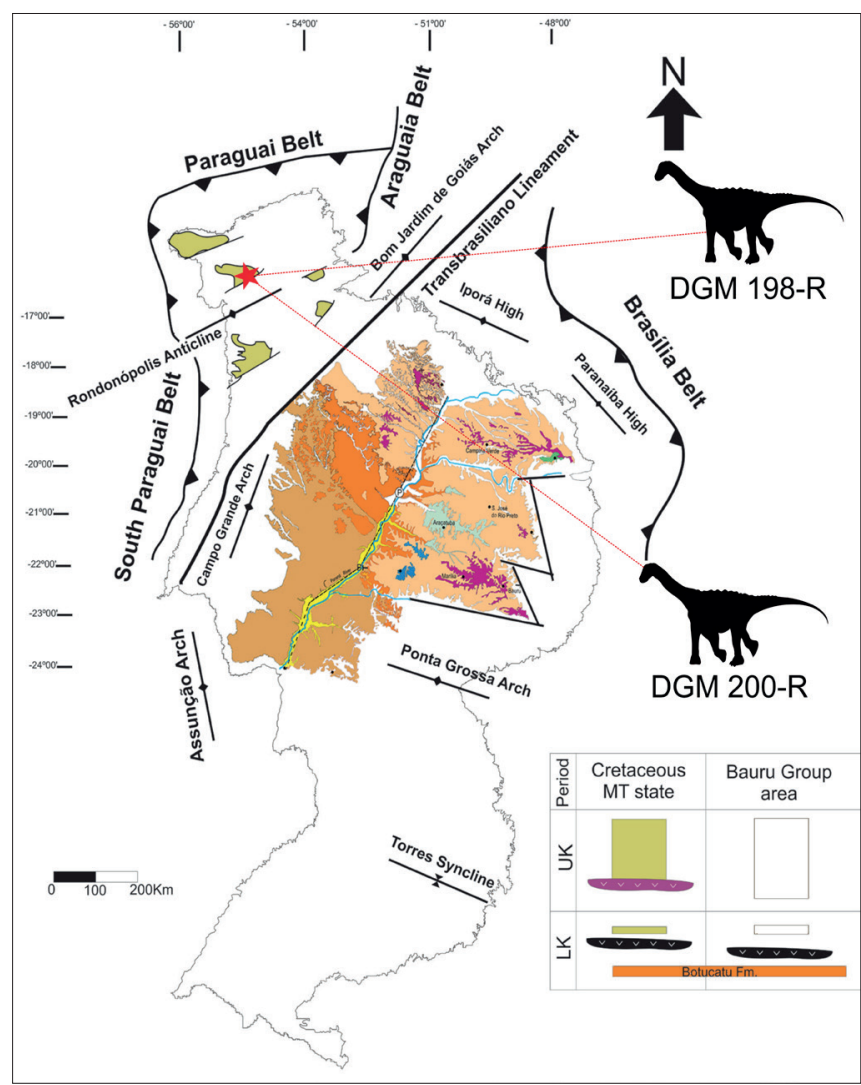

Figure 1. Geological map of the Bauru Group (Upper Cretaceous), with focus on the Mato Grosso state. The red star indicates the Morro do Cambambe locality and the silhouettes indicate the specimens. Modified from Bandeira et al. (2019). Aeolosaurini silhouette from Arthur S. Brum, available on PhyloPic.

\section{MATERIAL AND METHODS}

\subsection{Institutional abbreviations}

DGM-R, Museu de Ciências da Terra; CPRM (Companhia de Pesquisa de Recursos Minerais, the former Divisão de Geologia e Mineralogia), Rio de Janeiro, Brazil.

\subsection{Materials}

We sectioned the following specimens, previously described in Bandeira et al. (2019) and assigned to Aeolosaurini: DGM 198-R, a cervical rib and a dorsal rib; and the chevron DGM 200-R. Different portions of the bones were sectioned (Fig. 2) to assess bone regional variations and infer comparative life histories. According to Bandeira et al. (2019), DGM 198-R and DGM 200-R probably belonged to different individuals.

A

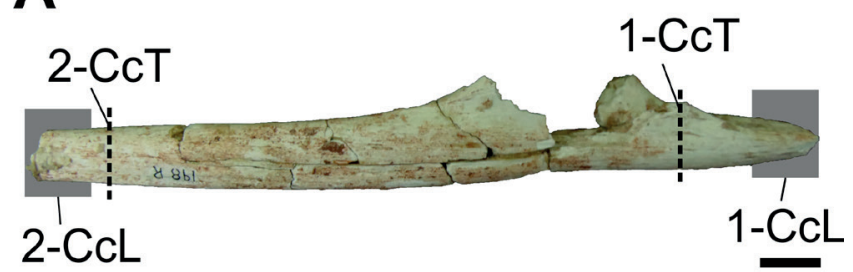

B
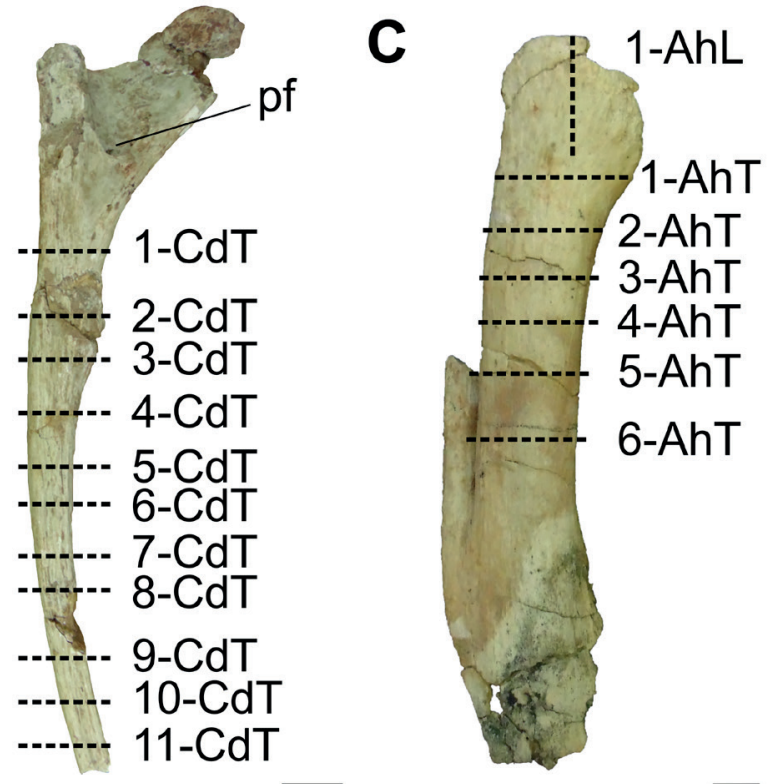

Figure 2. Sections performed in the specimens DGM 198-R, comprising a cervical (a) and a dorsal rib (b), and DGM 200-R, comprising a haemal arch (c). Abbreviations: AhL, longitudinal section of the haemal arch; AhT, transversal section of the haemal arch; CcL, longitudinal section of the cervical rib; CcT, transversal section of the cervical rib; CdT, transversal section of the dorsal rib; pf, pneumatic foramen. Scale bars equal $10 \mathrm{~mm}$.

\subsection{Palaeohistological protocols}

The slide preparation followed the commonly used palaeohistological analysis (Chinsamy \& Raath, 1992; Chinsamy-Turan, 2005; Lamm, 2013). We embedded the sectioned regions of the fossil bones into a clear epoxy resin ( Rp 031 - Siligel Comércio Ltda) and sectioned them by a precision router. We mechanically thinned out 
the resin blocks in a wet metallographic polishing machine (Arotec AROPOL VV-PUD®) until it reached a final thickness of 30-60 microns. The photomicrographs were taken under a light transition microscope Nikon Eclipse E200®. The high-resolution photomicrographs were uploaded on the Morphobank online repository (O'Leary \& Kaufman, 2012) and are available at the access link http://morphobank.org/permalink/?P3797.

The nomenclature used in the microstructural descriptions follow Francillon-Vieillot et al. (1990), Reid (1997), Chinsamy-Turan (2005), and Prondvai et al. (2014), the last used in the fibrolamellar bone matrix description. The relative bone appositional rates (Table 1) followed herein assumed the well vascularised fibrolamellar bone as the fastest deposition and the poorly-vascularised lamellar as the slowest, including the cyclical Lines of Arrested Growth - LAGS as discussed in the literature (Castenet et al., 2000; de Margerie et al., 2002; Starck \& Chinsamy, 2002; de Margerie, 2004).

Our skeletrochronological inferences followed the Three Front Model (Mitchell \& Sander, 2014). The subdivisions of the Remodeling Front (RmF; Haversian Substitution Front in Mitchell \& Sander, 2014) followed Mitchell et al. (2017). We assumed the sexual maturity as marked in all bones of the skeleton by the allocation of organism energy for the reproduction (growth inflection period), which can be microstructurally characterised by the transition to low bone depositional rates, advanced remodelling and endosteal bone (Reid, 1997; Lee \& Werning, 2008; Waskow \& Sander, 2014; Padian et al., 2016; Prondvai, 2017; Waskow \& Mateus, 2017). We assumed the somatic maturity to be the full size of a bone characterised by the advanced remodelling and/or deposition of an External Fundamental System (EFS). Skeletal elements exhibiting advanced remodelling or EFS are considered to be of an organism with an advanced ontogenetic stage (e.g. Kellner et al., 2013, 2019).

The ontogenetic stages used here were: juvenile, subadult, adult and senescent. The microstructural features used to the classification of these stages were: 1) Juvenile: transition from fast to low bone apposition and moderate remodelling and endosteal bone; 2) Subadult:

Table 1. Descriptive codes to the three fronts used in the study and its interpretations.

\begin{tabular}{|c|c|c|c|}
\hline Front & Code & Description & First order interpretation \\
\hline \multirow[t]{6}{*}{$\mathrm{AF}$} & F-L & Fibrolamellar bone tissue with longitudinal vascular canals. & Fast continuous growth. \\
\hline & $\mathrm{pF}-\mathrm{L}$ & $\begin{array}{l}\text { Periosteal fibrolamellar complex, rich in woven bone. Longitudinal to } \\
\text { radial vascular canals. }\end{array}$ & Fast secondary periosteal bone deposition. \\
\hline & eF-Lr & $\begin{array}{l}\text { Endosteal fibrolamellar complex, rich in woven bone. Vascular canals } \\
\text { vary from longitudinal to radial. }\end{array}$ & Fast secondary endosteal bone deposition. \\
\hline & $\mathrm{Fp}-\mathrm{Lr}$ & $\begin{array}{l}\text { Fibrolamellar complex with more contribution of parallel fibered } \\
\text { bone. Longitudinal vascular canals organized into rows, which can be } \\
\text { interlayered by LAGs. Some Sharpey's fibers can be observed regionally. }\end{array}$ & Moderate cyclical growth. \\
\hline & Pl-L & $\begin{array}{l}\text { Transition between parallel-fibered and lamellar bone, with rare narrow } \\
\text { longitudinal vascular canals. Some Sharpey's fibers can be observed } \\
\text { regionally. }\end{array}$ & Slowly cyclical growth. \\
\hline & EFS & External Fundamental System. & Slowly cyclical growth, indicating highly bone maturity. \\
\hline \multirow[t]{3}{*}{$\mathrm{RmF}$} & $\mathrm{D}$ & Dense secondary bone, with osteons reaching three or more generations. & Advanced remodeling. \\
\hline & Dr & $\begin{array}{l}\text { Dense secondary bone, with osteons reaching three or more generations. } \\
\text { Occurrence of transition between resorption cavities and secondary } \\
\text { osteon. }\end{array}$ & Moderate to advanced remodeling. \\
\hline & $\mathrm{D}^{\prime}$ & $\begin{array}{l}\text { Dense secondary bone, with osteons reaching two generations and rich } \\
\text { in interstitial matrix. }\end{array}$ & Moderate remodeling. \\
\hline \multirow[t]{3}{*}{ RF } & $\mathrm{Dp}$ & $\begin{array}{l}\text { Defined medullary cavity, with thick and numerous rows of endosteal } \\
\text { bone and wide chambers. Resorptions cavities advance through compact } \\
\text { bone. }\end{array}$ & Pneumatic medullary cavity. \\
\hline & $\mathrm{D} 1$ & $\begin{array}{l}\text { Defined medullary cavity, with thick endosteal bone and wide chambers. } \\
\text { Resorptions cavities advance through compact bone. }\end{array}$ & Medullary cavity with high bone maturity. \\
\hline & $\mathrm{U}$ & $\begin{array}{l}\text { Undefined medullary cavity, with rare and sparse resorption cavities or } \\
\text { by the absence of them. }\end{array}$ & Unformed medullary cavity. \\
\hline
\end{tabular}


microstructure with periosteal region showing low bone apposition and advanced remodelling, which corresponds to the growth inflection period (sexual maturity); 3) Adult: periosteal deposition of lamellar bone and decrease in vascularization and advanced remodelling, reaching the periosteal region; 4) Senescent: wide occurrence of EFS and advanced remodelling, corresponding to the full growth bone (somatic maturity) in most of the skeleton.

\section{RESULTS}

\subsection{Microstructure}

\subsubsection{Cervical rib (DGM 198-R; Figures 3-4; Table 2)}

The medullar cavity is reduced, presenting only isolated resorption cavities. Both transversal and longitudinal sections show a longitudinal isotropic microstructure. A
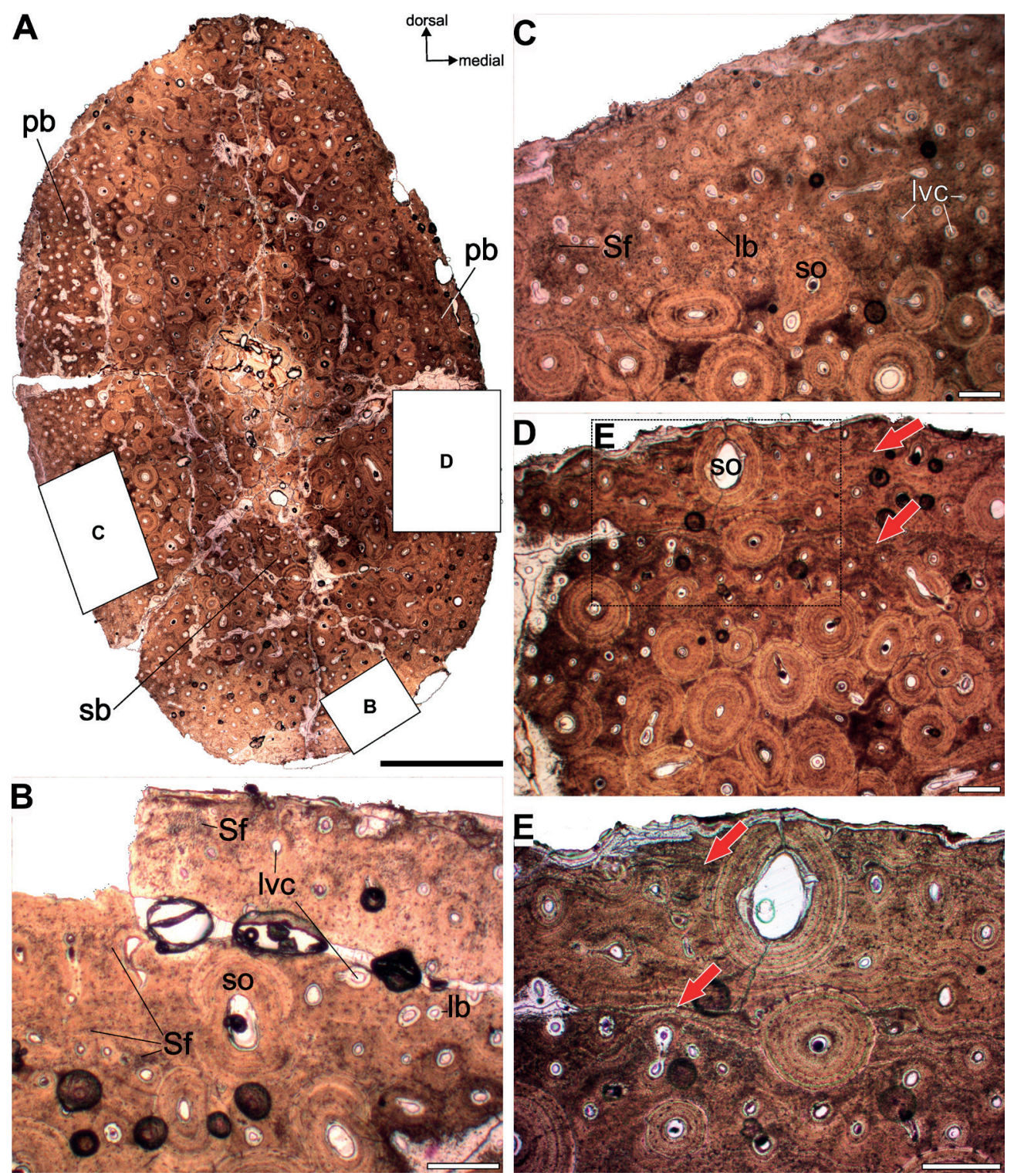

Figure 3. Photomicrographs of the slide DGM 198-R-2-CcT. a) Panoramic image of the slide. b) Fibrolamellar complex rich in woven bone, with thin lamellar bone filling the longitudinal vascular canals and some Sharpey's fibres in the woven matrix. c) Detail of the disorganised longitudinal vascular canals in the fibrolamellar complex. d) Detail of the fibrolamellar complex in the lateral margin of the section. The fibrolamellar complex varies centrifugally from rich in woven to rich in parallel-fibered bone and the longitudinal canals become organised into rows (interlayered by two LAGs) in the periosteal region. e) Detail of the fibrolamellar complex rich in parallel-fibered bone, with rows of longitudinal canals interlayered by two LAGs. lb: lamellar bone; lvc: longitudinal vascular canal; pb: primary bone; sb: secondary bone; Sf: Sharpey’s fibres, so: secondary osteon. Red arrows indicate LAGs. Scale bars equal $1 \mathrm{~mm}$ in (a) and $100 \mu \mathrm{m}$ in (b-e). 
Table 2. Description of the fronts observed in the cervical rib DGM 198-R. See abbreviations in Table 1 and Figure 2.

\begin{tabular}{|c|c|c|c|c|c|c|}
\hline Specimen & Section & $\mathbf{A F}$ & $\mathbf{R m F}$ & RF & Observations & Second order inferences \\
\hline \multirow[t]{2}{*}{$\begin{array}{l}\text { Cervical rib } \\
\text { (DGM 198-R) }\end{array}$} & $1-\mathrm{CcT}$ & $?$ & Dr & $\mathrm{U}$ & $\begin{array}{l}\text { Rich in longitudinal } \\
\text { Sharpey's fibers. }\end{array}$ & Asymptotic growth. Strong muscular influence. \\
\hline & 2-CcT & $\begin{array}{l}\text { Fp-Lr; } \\
\text { F-L }\end{array}$ & $\mathrm{D}$ & $\mathrm{U}$ & $\begin{array}{l}\text { Rich in longitudinal } \\
\text { Sharpey's fibers. Two } \\
\text { LAGs. }\end{array}$ & $\begin{array}{l}\text { Continuous growth regionally alternated by cyclical. Strong } \\
\text { muscular influence. }\end{array}$ \\
\hline
\end{tabular}

dense secondary bone tissue filled most of the compact bone, with more than three generations of secondary osteons. The most posterior transversal section exhibits more primary bone, with a variation of the fibrolamellar complex. In this section, the lateral margin presents a fibrolamellar complex with longitudinal vascular canals, while close to the medial margin, this bone complex is rich in parallel fibres, with narrow longitudinal canals organised into rows. In the medial region, we observed at least one LAG. Both longitudinal and transversal sections of this cervical rib show longitudinal Sharpey's fibres (Fig. 4).

\subsubsection{Dorsal rib (DGM 198-R; Figures 5-7; Table 3)}

A thick endosteal bone delimited the medullar cavity (Table 3). Proximally, the dorsal rib is filled by wide chambers and the thick endosteal bone exhibited alternated rows of longitudinal osteocyte lacunae. Although the medullar cavity of the mid-distal portions was partially eroded, the endosteal bone of these sections was thinner than that the one observed in the proximal regions. In addition, the preserved cavities were narrower. Such distinction between these portions of the bones and the wide foramen in the articulation of the rib indicated that this bone was pneumatic and that its pneumatisation extended only through the one third of the dorsal rib in the proximal portion.

The secondary bone is dense, with more than three generations of secondary osteons reaching in all sections. The samples of the mid portions show regions of the section with secondary bone reaching two generations and being rich in interstitial matrix. In the mid-distal portions, the secondary bone shows large resorption cavities internally filled by lamellar bone, marking the transition to the secondary osteons.

The primary bone is composed of a variation of the fibrolamellar bone complex (Figs. 5-6). The inner regions comprised a dense woven bone matrix. The vascular canals are numerous and wide, and longitudinally oriented. The outer regions are mostly composed of parallel-fibered bone. The vascular canals are narrow and although longitudinal, they are organised into rows, interlayered by growth marks,
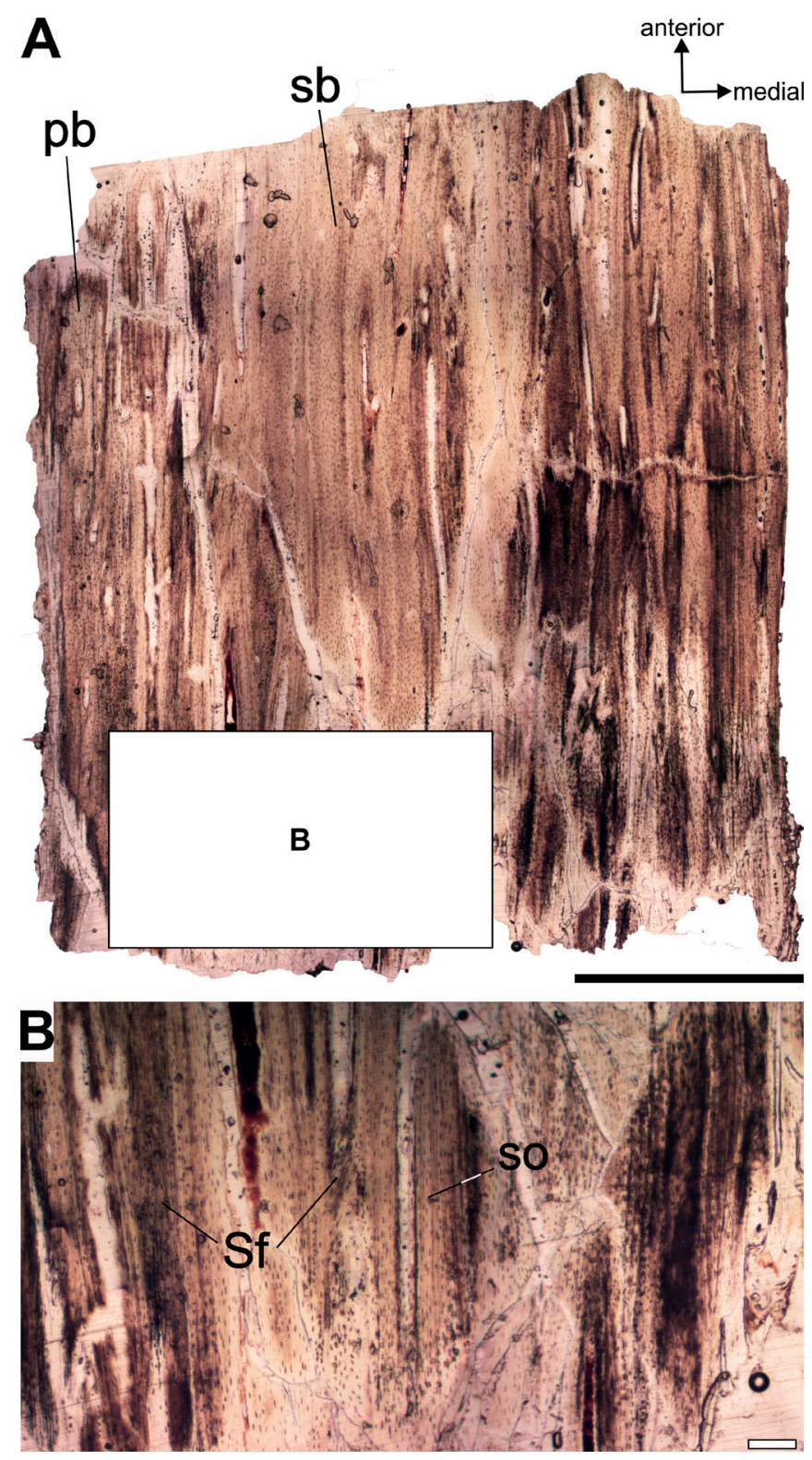

Figure 4. Photomicrographs of the slide DGM 198-R-2-CcL. a) Panoramic image of the slide. b) Detail of the longitudinal arrangement of the Sharpey's fibres. pb: primary bone; sb: secondary bone; Sf: Sharpey's fibres, so: secondary osteon. Scale bars equal $1 \mathrm{~mm}$ in (a) and $100 \mu \mathrm{m}$ in (b). 
Table 3. Description of the fronts observed in the dorsal rib DGM 198-R. See abbreviations in Table 1 and Figure 2.

\begin{tabular}{|c|c|c|c|c|c|c|}
\hline Specimen & Section & $\mathbf{A F}$ & $\mathbf{R m F}$ & $\mathbf{R F}$ & Observations & Second order inferences \\
\hline \multirow[t]{11}{*}{$\begin{array}{l}\text { Dorsal rib } \\
\text { (DGM 198-R) }\end{array}$} & $1-\mathrm{CdT}$ & Fp-Lr; FL; eF-Lra & $\mathrm{D}$ & Dl & Two LAGs. & $\begin{array}{l}\text { Continuous growth alternated by } \\
\text { cyclical. }\end{array}$ \\
\hline & $2-\mathrm{CdT}$ & pF-L; F-L; eF-Lra & $\mathrm{D}$ & Dl & None. & $\begin{array}{l}\text { Continuous growth. Secondary } \\
\text { periosteal and endosteal growth. }\end{array}$ \\
\hline & $3-\mathrm{CdT}$ & pF-L; L-A; Fp-Lr; F-L; eF-Lra & $\mathrm{D}$ & Dl & None. & $\begin{array}{l}\text { Continuous growth alternated by } \\
\text { cyclical. Secondary endosteal and } \\
\text { periosteal growth. }\end{array}$ \\
\hline & 4-CdT & Fp-Lr; F-L; eF-Lra & $\operatorname{Dr}$ & Dl & Three to four LAGs. & $\begin{array}{l}\text { Continuous growth. Secondary } \\
\text { endosteal growth. }\end{array}$ \\
\hline & $5-\mathrm{CdT}$ & $\mathrm{F}-\mathrm{L} ; \mathrm{Fp}-\mathrm{Lr}$ & $D^{\prime}$ & Dl & Three LAGs. & $\begin{array}{l}\text { Continuous growth alternated by } \\
\text { cyclical. }\end{array}$ \\
\hline & $6-\mathrm{CdT}$ & Fp-Lr & $\mathrm{D} ; \mathrm{D}^{\prime}$ & $\mathrm{Dl}$ ? & Two LAGs. & Cyclical growth. \\
\hline & 7-CdT & F-L; Fp-Lr & Dr & Dl & Three LAGs. & $\begin{array}{l}\text { Continuous growth alternated by } \\
\text { cyclical. }\end{array}$ \\
\hline & $8-\mathrm{CdT}$ & Fp-Lr & $\operatorname{Dr}$ & $?$ & Three LAGs. & Cyclical growth. \\
\hline & 9-CdT & F-L; Fp-Lr & $\mathrm{D}$ & Dl & Four LAGs. & $\begin{array}{l}\text { Continuous growth alternated by } \\
\text { cyclical. }\end{array}$ \\
\hline & $10-\mathrm{CdT}$ & $\mathrm{Fp}-\mathrm{Lr}$ & $\mathrm{D}$ & $\mathrm{D} 1 ?$ & Four LAGs. & Cyclical growth. \\
\hline & $11-\mathrm{CdT}$ & F-L; Fp-Lr & $\mathrm{D}$ & $\mathrm{Dl} ?$ & Two LAGs. & $\begin{array}{l}\text { Continuous growth alternated by } \\
\text { cyclical. }\end{array}$ \\
\hline
\end{tabular}
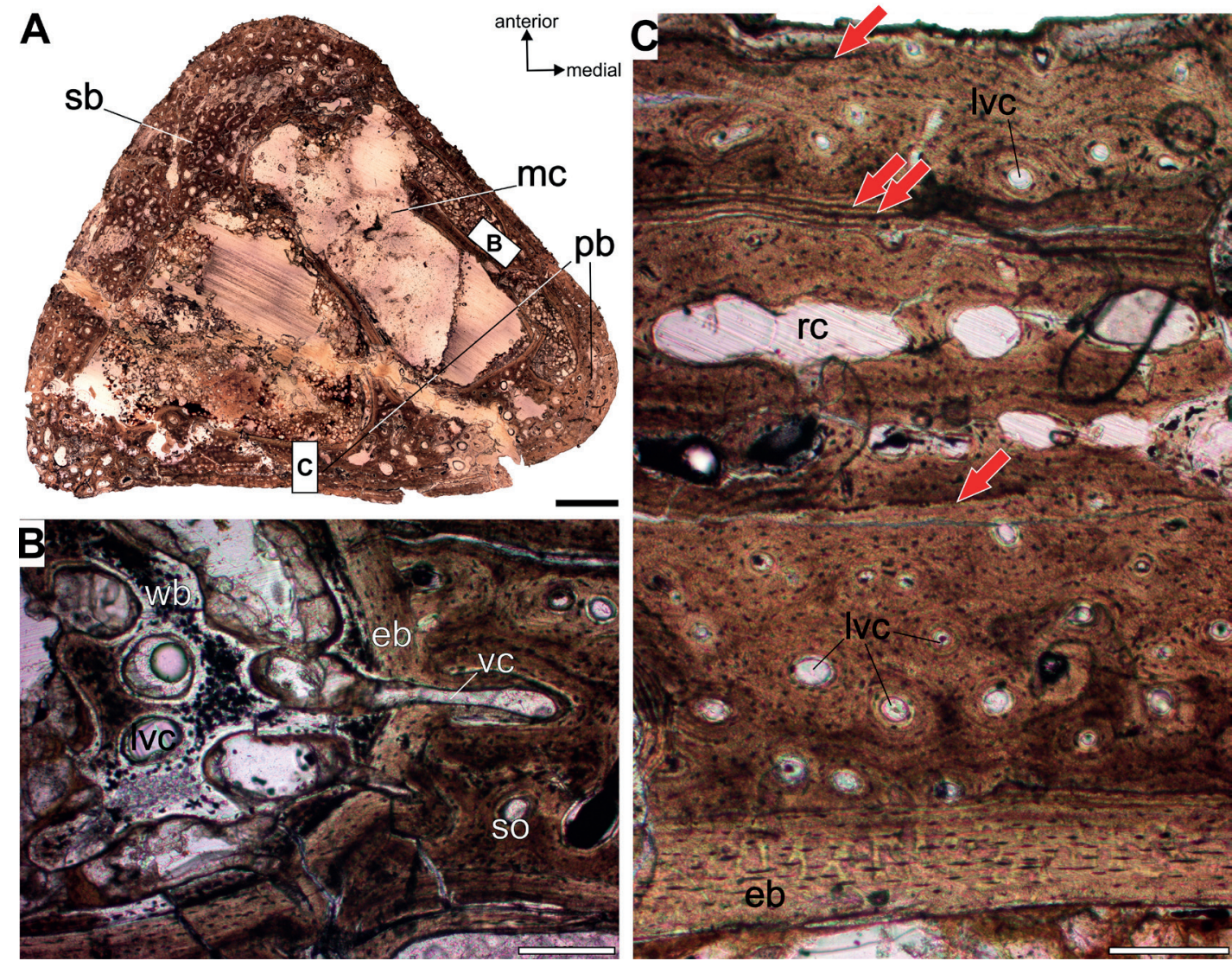

Figure 5. Photomicrographs of the slide DGM 198-R-4-CdT. a) Panoramic image of the slide. b) Detail of the bone outgrowth covering the endosteal bone. This bone is rich in woven bone tissue. c) Variation of the fibrolamellar complex, with the internal cortex rich in woven bone and longitudinal canals and the outer cortex rich in parallel fibered bone with rows of longitudinal canals, interlayered by three LAGs. Detail of the double LAGs. eb: endosteal bone; lvc: longitudinal vascular canal; mc: medullary cavity; pb: primary bone; rc: resorption cavity; sb: secondary bone; Sf: Sharpey's fibres, so: secondary osteon; vc: vascular canal; wb: woven bone. Red arrow indicates LAG. Scale bars equal $1 \mathrm{~mm}$ in (a) and $100 \mu \mathrm{m}$ in (b-c). 
in which we commonly found LAGs. In some regions of the sections, close to the anterior or posterior edges of the sections, we observed Sharpey's fibres. The LAGs count varied from two to four, due to the regional variation in
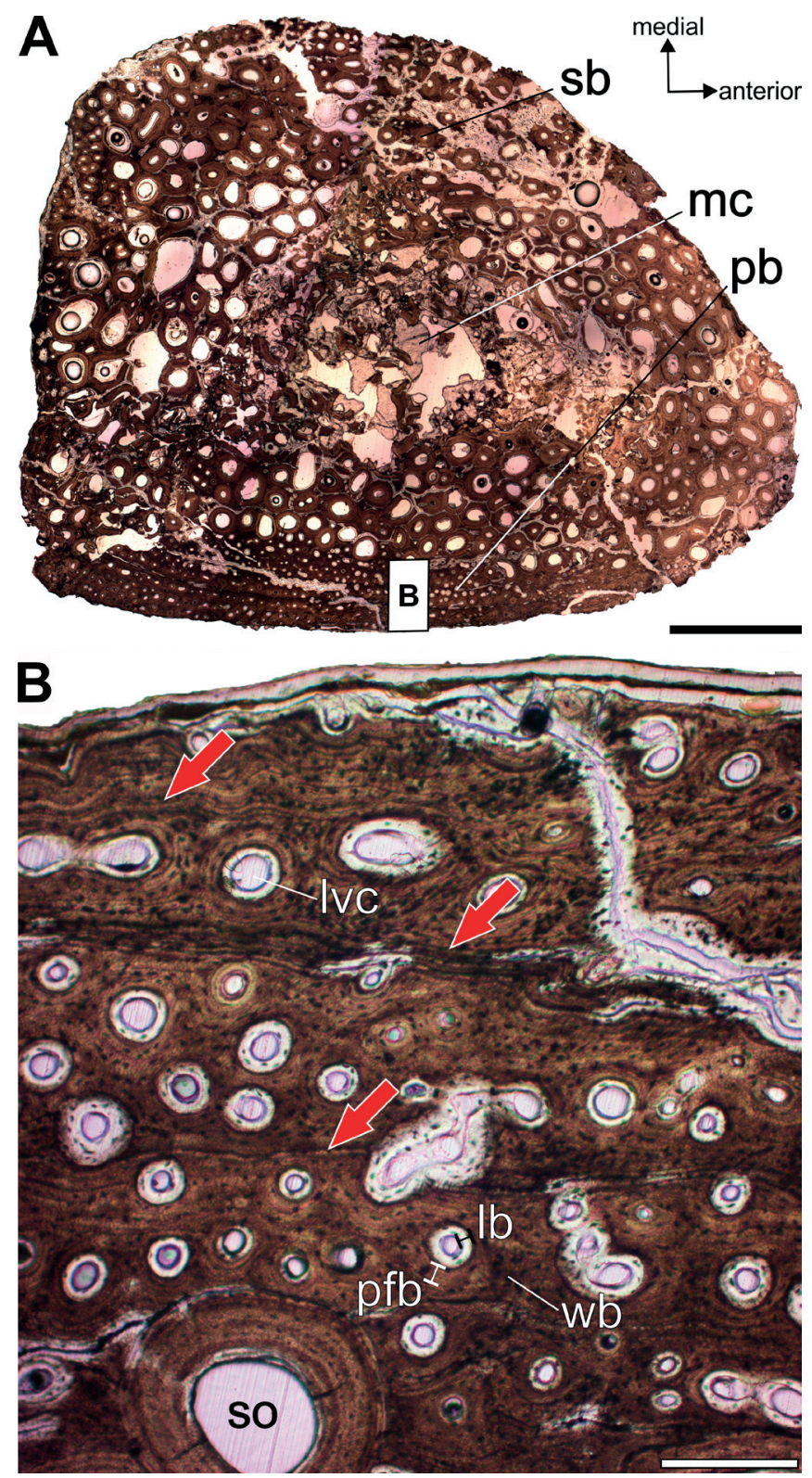

Figure 6. Photomicrographs of the slide DGM 198-R-8-CdT. a) Panoramic image of the slide. b) Detail of the primary bone and the variation of the fibrolamellar complex. The inner regions rich in woven bone and dispersed longitudinal canals, centripetally filled by lamellar bone, while the outer regions are rich in parallel-fibered bone and show more LAGs. lb: lamellar bone; lvc: longitudinal vascular canal; mc: medullary cavity; pb: primary bone; pfb: parallel fibered bone; rc: resorption cavity; sb: secondary bone; Sf: Sharpey's fibres, so: secondary osteon; vc: vascular canal; wb: woven bone. Red arrows indicate LAGs. Scale bars equal $1 \mathrm{~mm}$ in (a) and $100 \mu \mathrm{m}$ in (b). bone section, marking differential bone growth. The midto-distal portions exhibit higher numbers of LAGs count.

We observed an endosteal and periosteal secondary bone growth in the proximal portions of the dorsal rib, close to the osseous knob visible externally (Figs. 5, 7). Layers of bone were deposited over the endosteal bone and the most external rows of the cortex, marking a drift. The matrix varied from woven to fibrolamellar, rich in osteocyte lacunae, indicating a fast and active osteogenesis. The vascular canals were wide and varied from longitudinal to radial, with some of them exhibiting a thin layer of lamellar bone.

\subsubsection{Haemal arch (DGM 200-R; Figures 8-9; Table 4)}

The medullary cavity is medially located in all transversal sections. The cavities are wide, and occupied most of the area of the sections, especially on the proximal portions of the bone. The medullary cavity also shows endosteal bone as the one observed in the apneumatic portions of the dorsal rib DGM 198-R. The longitudinal section reveals that the cavities varied proximo-distally along the proximal ramus, being narrow close to the articulator facet at the same time longitudinal and wide close to the distal blade.

The secondary bone is dense and occupies most of the compact bone area. The secondary osteons reach more than three generations. Close to the articulation, resorption cavities are filled by lamellar bone, as observed in some sections of the dorsal rib. In both longitudinal and transversal sections, the contact between the primary and secondary bone tissues was markedly abrupt.

The primary bone varies proximo-distally in the bone. The proximal region was marked by being more restricted, rich in parallel-fibered and lamellar bone, with poor vascularization. Some regions show an EFS (Fig. 9). The sections of the most distal portions exhibit a fibrolamellar complex rich in parallel-fibered bone. In the anterior region of the most distal section, we observed a transition between the fibrolamellar complex, with woven bone in the inner cortex, to bone rich in parallel-fibered tissue in the outer cortex. The vascular canals are narrow and longitudinal, organised in rows. We observed at least two LAGs in the proximal ramus, which contrasted with the absence of growth marks in the portions close to the articulation. Some Sharpey's fibres occurs, especially in the anterolateral region in both longitudinal and transversal sections, exhibiting an oblique alignment with the longitudinal axis of the bone. 

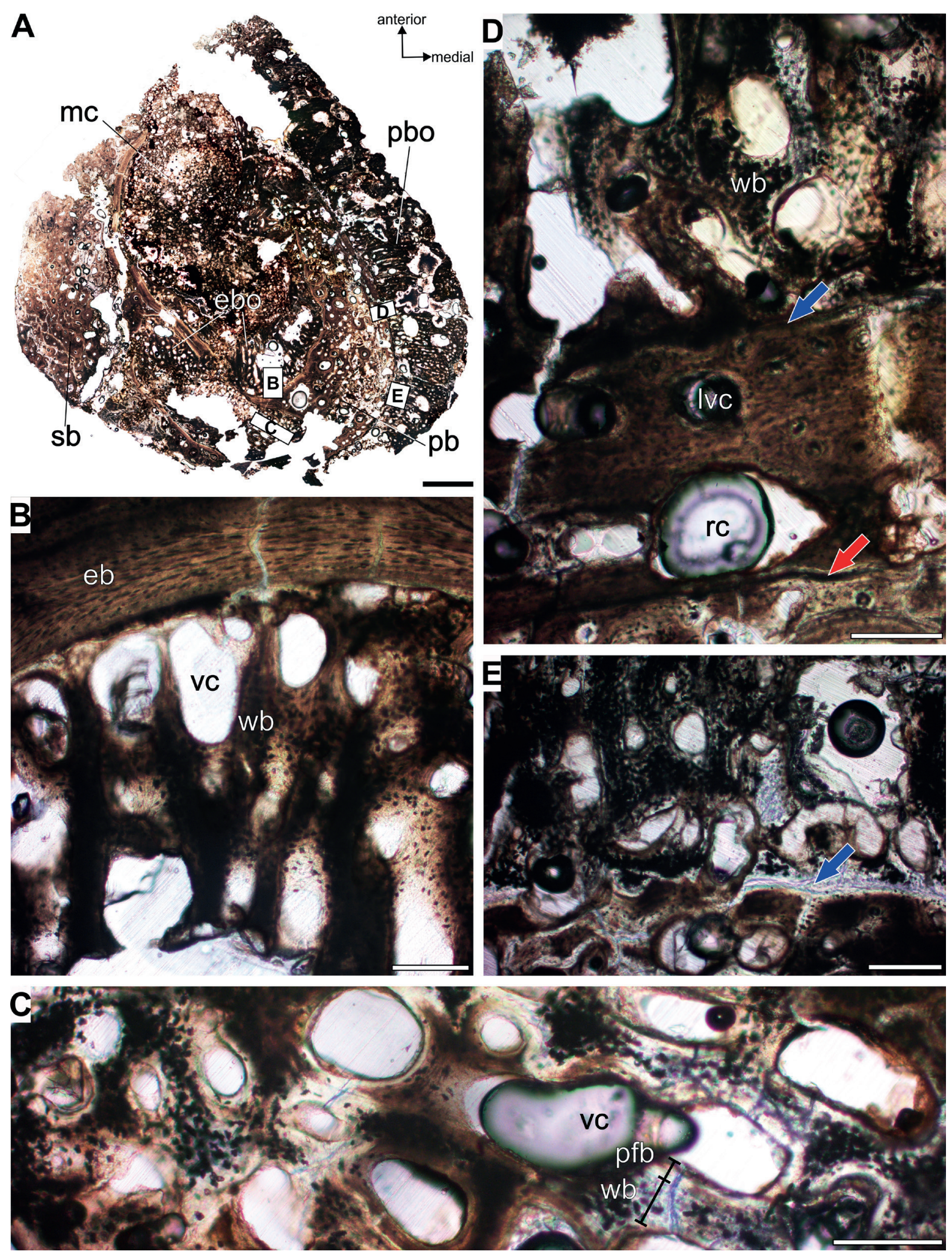

Figure 7. Photomicrographs of the slide DGM 198-R-8-CdT. a) Panoramic image of the slide. b) Detail of on the endosteal secondary growth, above the endosteal lamellar bone. c) Endosteal secondary growth bone, revealing a well vascularised fibrolamellar bone matrix. d) Detail of the bone drift, with the secondary periosteal growth, with a marked contact between a periosteal layer rich in parallel-fibered bone tissue and an outer with well vascularised woven bone. e) Growth mark in the secondary periosteal bone growth. eb: endosteal bone; ebo: endosteal bone outgrowth; lb: lamellar bone; lvc: longitudinal vascular canal; mc: medullary cavity; pbo: periosteal bone outgrowth; pb: primary bone; pfb: parallel fibered bone; rc: resorption cavity; sb: secondary bone; so: secondary osteon; vc: vascular canal; wb: woven bone. Red arrows indicate LAGs, while blue arrow indicates growth mark. Scale bars equal $1 \mathrm{~mm}$ in (a) and $100 \mu \mathrm{m}$ in (b-e). 
Table 4. Description of the fronts observed in the haemal arch DGM 200-R. See abbreviations in Table 1 and Figure 2.

\begin{tabular}{|c|c|c|c|c|c|c|}
\hline Specimen & Section & $\mathbf{A F}$ & $\mathbf{R m F}$ & RF & Observations & Second order inferences \\
\hline \multirow{5}{*}{$\begin{array}{l}\text { Haemal arch } \\
\text { (DGM 200-R) }\end{array}$} & 1-AhT & EFS & Dr & $\mathrm{Dl}$ & None. & Asymptotic growth. \\
\hline & 2-AhT & Pl-L; EFS & & $\mathrm{Dl}$ & None. & Slowly cyclical growth. \\
\hline & 3-AhT & Fp-Lr; F-L; Pl-L & & $\mathrm{Dl}$ & $\begin{array}{l}\text { F-L in anterior regions } \\
\text { and Pl-L in posterior. } \\
\text { Two LAGs. }\end{array}$ & $\begin{array}{l}\text { Continuous growth alternated by cyclical. } \\
\text { Regions in slowly cyclical growth. }\end{array}$ \\
\hline & 5-AhT & Fp-Lr; F-L & $\mathrm{D}$ & $\mathrm{Dl}$ & Two LAGs. & Continuous growth alternated by cyclical. \\
\hline & 6-AhT & Fp-Lr; F-L & $\mathrm{D}$ & $\mathrm{Dl}$ & Two LAGs. & Continuous growth alternated by cyclical. \\
\hline
\end{tabular}
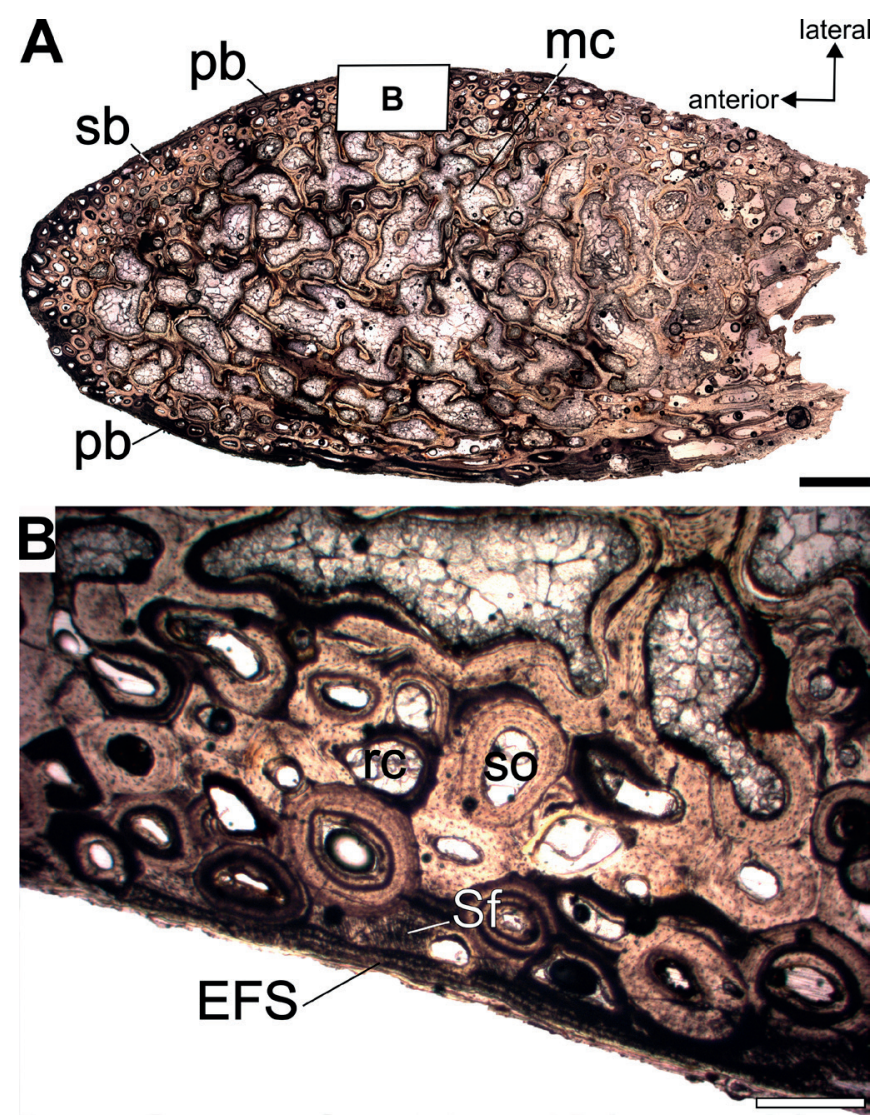

Figure 8. Photomicrographs of the slide DGM 200-R-2-AhT. a) Panoramic image of the slide. b) Periosteal lateral region exhibiting EFS and advanced remodelling. EFS: External Fundamental System; mc: medullary cavity; pb: primary bone; rc: resorption cavity; sb: secondary bone; Sf: Sharpey's fibres; so: secondary osteon; vc: vascular canal; wb: woven bone. Scale bars equal $1 \mathrm{~mm}$ in (a) and $100 \mu \mathrm{m}$ in (b).

\subsection{Ontogenetic inferences}

The cervical rib (DGM 198-R) exhibits an antero-posterior variation of the microstructure, which indicates that the bone growth varied along this axis. The anterior portion of the posterior process is mostly filled by secondary bone. Regarding the posterior portion, it exhibits a regional primary bone, varying from a fast to slow growth phase. We interpret such differences in maturity as a variation in the bone development, with the anterior regions reaching advanced bone maturity before the posterior ones. These microstructures indicate that this bone reached an advanced maturity. However, it is difficult to infer only from cervical rib microstructure, especially from posterior processes, the ontogenetic stage of the whole organism, due to the bone maturity of cervical ribs reaching early in ontogeny by its metaplastic origin (Klein et al., 2012).

The dorsal rib (DGM 198-R) exhibits a proximo-distal microstructural variation. The maximum number of LAGs observed in the mid-to-distal portions of the bone indicates that some growth marks were eroded by the remodelling/ resorption. The vascularization decreases from endosteal to periosteal regions, as well as the distance between the LAGs in the outer cortex and the advanced remodelling indicates that the organism reached sexual maturity and is a subadult.

The haemal arch (DGM 200-R) varies in microstructure proximo-distally. The proximal region, close to the articulation was fulfilled by secondary bone, with a restrict EFS, indicating a somatic maturity. The distal portion of the proximal ramus exhibits a record of continuous growth, alternated by low cyclical growth (with transition between parallel-fibered to lamellar bone in some regions of the section), and advanced remodelling. Such features indicate 


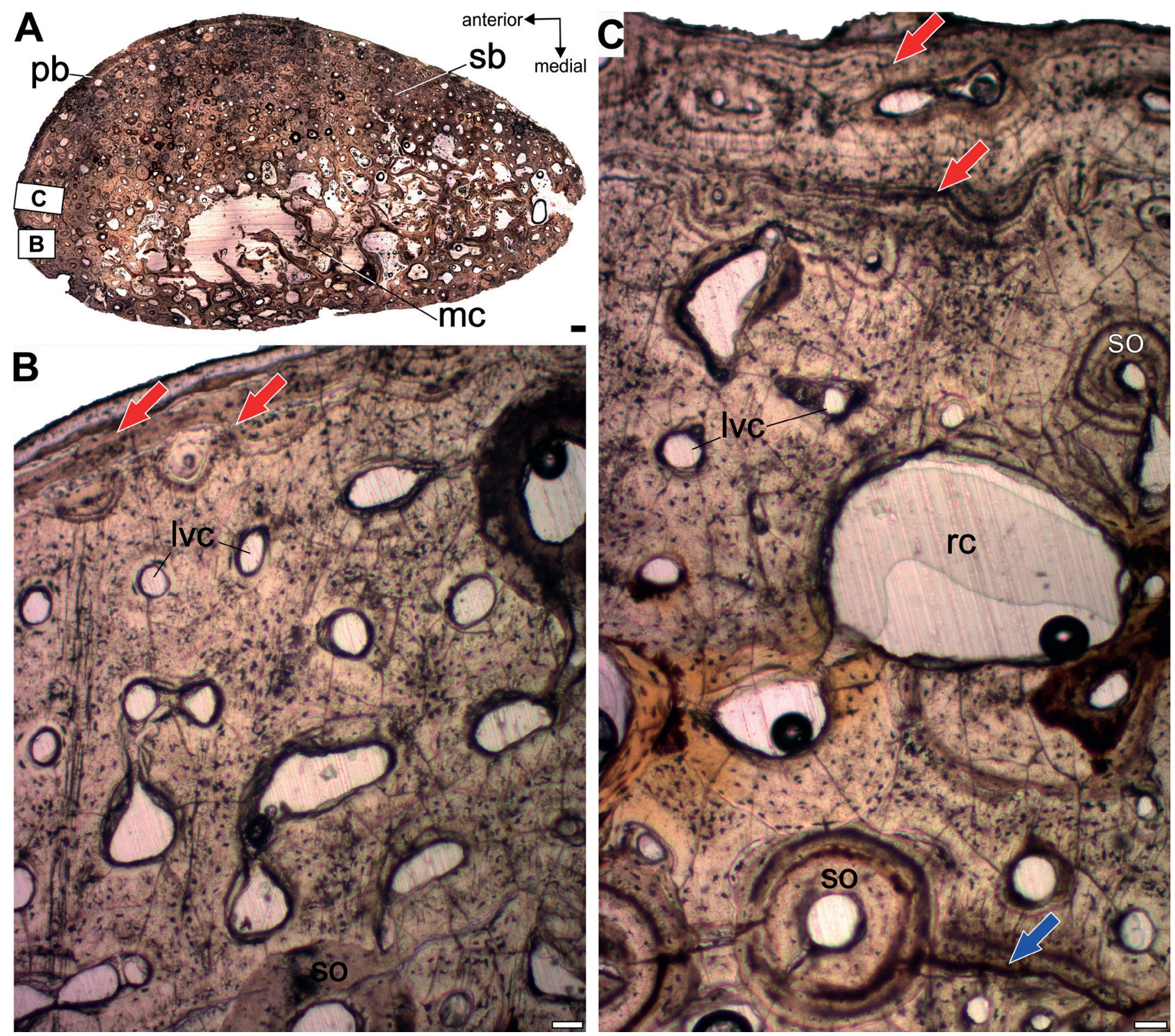

Figure 9. Photomicrographs of the slide DGM 200-R-3-AhT. a) Panoramic image of the slide. b) Detail of the primary bone, with the inner cortex exhibiting a fibrolamellar complex rich in woven bone, and the outer cortex with a thin layer of zonal bone rich in parallel fibred bone. c) Regional variation of the pattern found in the primary bone, with detail of the increase of the thickness of the zonal bone in the outer cortex. Abbreviations: lvc: longitudinal vascular canal; mc: medullary cavity; pb: primary bone; rc: resorption cavity; sb: secondary bone; so: secondary osteon. Red arrows indicate LAGs, while blue arrow indicates growth mark. Scale bars equal $1 \mathrm{~mm}$ in (a) and $100 \mu \mathrm{m}$ in (b-c).

an asymptotic growth of the bone, which we interpret as typical of adult stages.

We inferred that the fossil bones DGM 198-R (cervical and dorsal ribs) belongs to a subadult semaphoront, while DGM 200-R could belong to an adult one. The advance of primary bone and the variation from fast to slow growth stages in both dorsal and cervical rib indicates that they shared a similar ontogenetic stage. A different microstructure occurs in the haemal arch, with advanced EFS and reduced primary bone. Our ontogenetic assignment is supported by the relative bone sizes with the ribs in DGM 198-R, being smaller when compared to the haemal arch DGM 200-R, which belongs to a larger individual. Therefore, the osteohistology supports the assignment of Bandeira et al. (2019) to these three bones. 


\section{DISCUSSION}

\subsection{Microstructure}

The microstructure of the cervical rib was similar to the one observed in neosauropods in general, rich in primary bone Sharpey's fibres (Gallina, 2012; Klein et al., 2012). These fibres indicate the presence of muscle insertions and/or metaplastic bone (Organ \& Adams, 2005), which, in cervical ribs, also marks an anteroposterior transition between tissue of endochondral and metaplastic origin (Klein et al., 2012). Our observations indicate a transition between primary bone and regionally increase of metaplastic origin bone in the periosteal region of the cross-sections and along the distal portions of the posterior process of cervical ribs. Although our results corroborate the observations of Klein et al. (2012), we observe that the anterior portion of the posterior process of cervical ribs is marked by a primary fibrolamellar bone and periosteal metaplastic bone, indicating that there is a bone transition along the posterior process length. We also support the Tensile Member Hypothesis (TMH), in which the metaplastic posterior process suggests long cervical lateral muscles and consequently the transference of neck tensile forces over long distances (Christian \& Dzemski, 2007; Klein et al., 2012). The sections revealed that the analysed regions were endochondral bones under high influence of muscular insertion, particularly M. flexor colli lateralis, M. flexor colli medialis and M. longus colli ventralis (see Wedel \& Sanders, 2002).

The dorsal rib presented a pattern also found among basal neosauropods, with zonal bone (Waskow \& Sander, 2014; Woodruff et al., 2017). However, the pneumatisation and reduced number of LAGs were a remarkable distinction from the diplodocoids Apatasaurus, Diplodocus and the macronarian Camarasaurus. Compared to Gondwanatitan faustoi Kellner \& Azevedo, 1999, the dorsal rib is markedly smaller, which indicates a small sized aeolosaurini. Even exhibiting a comparatively small body length, the microstructure of the dorsal rib indicates a fast growth bone, with a brief cyclical bone deposition, as observed in other neosauropods (Waskow \& Sander, 2014; Woodruff et al., 2017).

Studies on the palaeohistology of haemal arches in Titanosauria are rare, comprising only isolated material (e.g., Gallina, 2012). Although this bone and the dorsal ribs are from distinct individuals, the microstructure was quite similar, suggesting similar bone growth regimes.

\subsection{Palaeopathology}

The periosteal and endosteal tissue observed in the dorsal rib presented a fibrolamellar pattern with radially oriented vascular canals. Such type of bone tissue was recognised as rapidly formed (Erickson \& Tumanova, 2000; Klein, 2004) and we interpreted this as a secondary bone growth covering the periosteal and endosteal lamellar bone. Such kind of structure was previously reported in subadult/ adult non-avian dinosaurs, occurring in situations of only periosteal growth, endosteal or both (Erickson \& Tumanova, 2000; Klein, 2004; Schweitzer et al., 2005; Hurum et al., 2006; Klein \& Sander, 2007; Lee \& Werning,

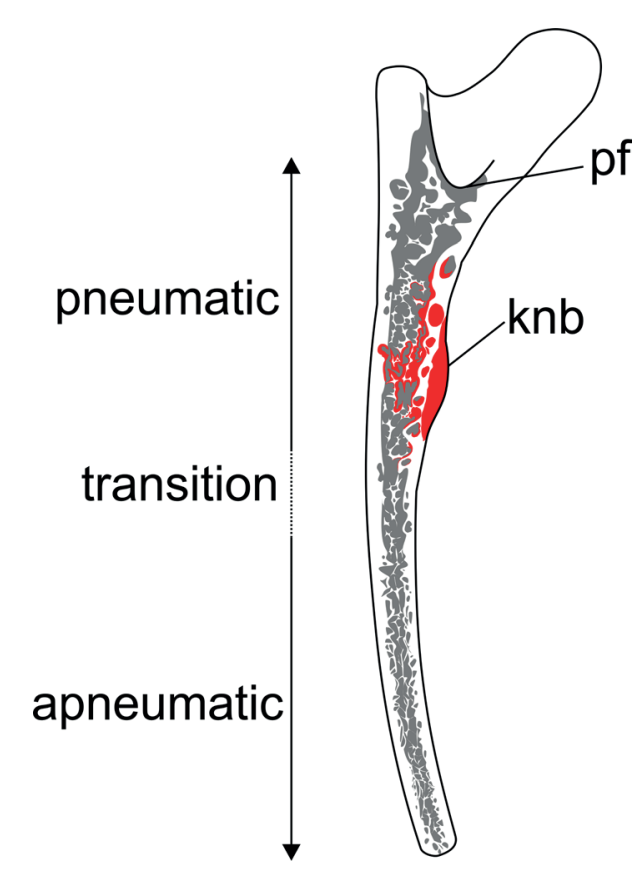

Figure 10. Scheme of the distribution of the pneumatization and the bone outgrowth (in red) observed along the sections of the dorsal rib (DGM 198-R). Unscaled.

2008; Chinsamy \& Tumarkin-Deratzian, 2009; Cerda et al., 2014; ). We characterised the bone observed in the dorsal rib DGM 198-R (Fig. 10) as: 1) Fibrolamellar bone rich in woven bone and osteocyte lacunae, with wide radial canals (some presenting thin lamellar bone); 2) Secondary outgrowth above endosteal bone and over the periosteal bone; 3) Endosteal outgrowth filling the pneumatic cavity; 4) Osseous knob (bleb) focalized on the posteromedial surface of the dorsal rib; 5) Bone outgrowth focalized on the osseous knob.

The similar microstructure of both secondary endosteal and periosteal bone tissue, provides a case very much alike retroviral osteopetrosis palaeopathologies, previously reported to dinosaurs by Chinsamy \& Tumarkin-Deratzian (2009) and Cerda et al. (2014). Retroviral osteopetrosis is a disease that affects the diaphysis of long bones in extant birds, characterised by periosteal and/or endosteal outgrowth (Bell \& Campbell, 1961; Holmes, 1961; Frank 
\& Franklin, 1982; Kirev, 1984). The outgrowth above the periosteal bone is clearly recognised as a pathology (Chinsamy \& Tumarkin-Deratzian, 2009). However, the osteopetrosis is characterized in birds as a diffuse bone reaction (Kirev, 1984), which contrasts with the focal occurrence reported herein.

Osseous blebs are reported in pulmonary diseases in humans and a Triassic marine reptile (Naples \& Rothschild, 2011; Anson et al., 2012; Surmik et al., 2018). As observed herein, they are focal in the bone. Other evidence that corroborates a pulmonary disease is the occurrence of such bleb in the posteromedial region of the dorsal rib, on the pleural surface, which indicates an intra-thoracic infection (Fig. 11), probably pneumonia (Naples \& Rothschild, 2011; Anson et al., 2012). Such palaeopathology is potentially related to tuberculosis due to the location, which is found among tuberculosis's cases, but not diagnostic. In addition, infections by Mycobacterium are wide distributed among mammals, reptiles and birds (Converse, 2007; Anson et al., 2012; Mitchell, 2012; Surmik et al., 2018). Therefore, we limit our inferences to a pneumonia case, probably related to tuberculosis.

The assignment of the endosteal outgrowth to the disease is not so clear, with some authors suggesting that it is a medullary bone homologue, as observed in extant birds during egg laying period, or a pathological case (Lee \& Werning, 2008; Chinsamy \& TumarkinDeratzian, 2009; Cerda et al., 2014; Prondvai \& Stein, 2014; Schweitzer et al., 2005, 2016; Prondvai, 2017). The medullary bone occurs in avian dorsal ribs (Canoville et al., 2019), although it was not recognized up to date to nonavian dinosaurs. Still, we exclude the assignment of the endosteal tissue found in the Cambambe specimen from a case of medullary bone homology due to its occurrence in a pneumatic cavity, in which the development of medullary bone is inhibited (Canoville et al., 2019). For this reason, we interpret it as related to a case of palaeopathology.

This endosteal bone tissue of the dorsal rib was also similar to records of non-avian medullary bone (Schweitzer et al., 2005; Lee \& Werning, 2008; Hübner, 2012), based on

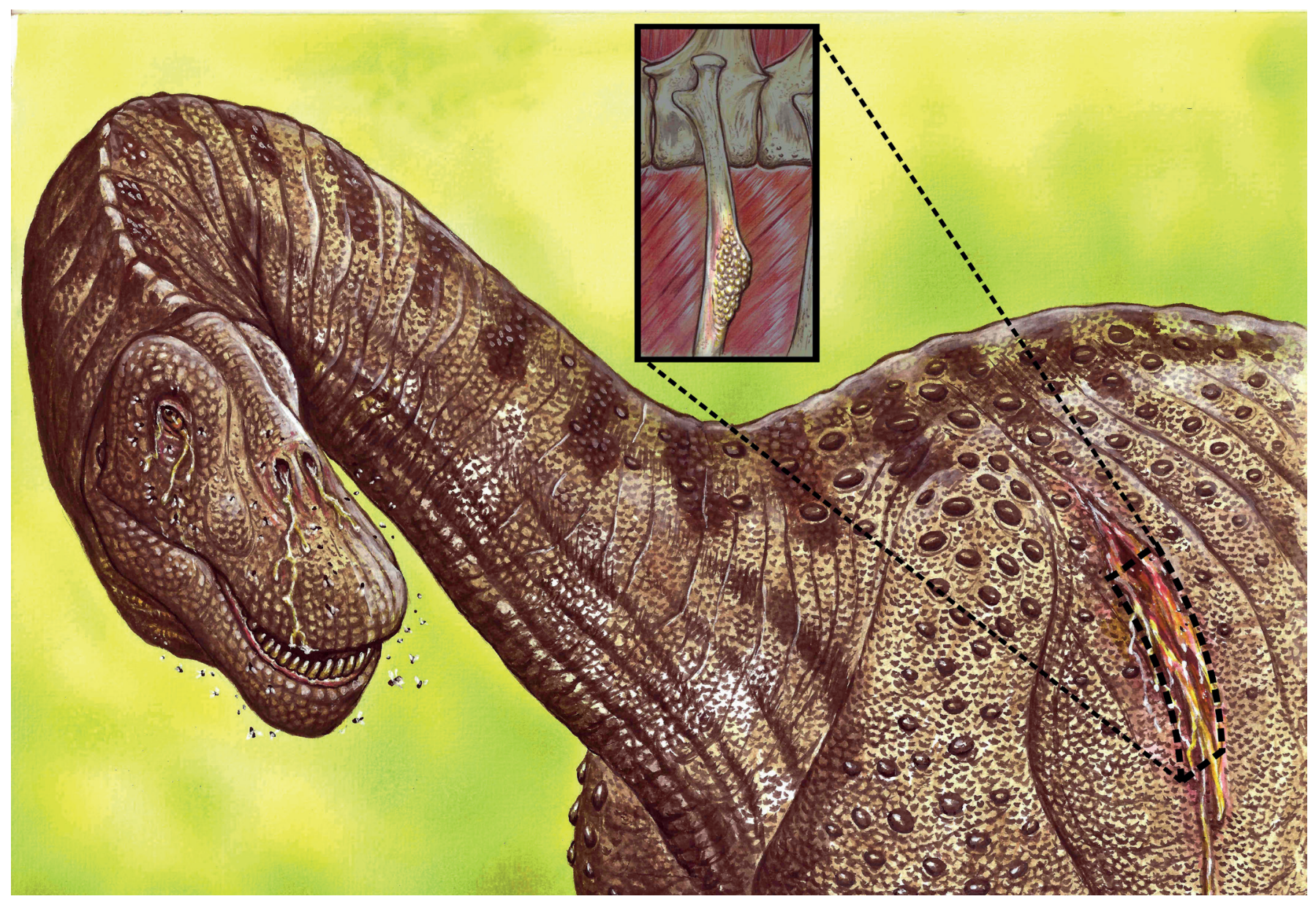

Figure 11. Representation of the titanosaurs from Cambambe with pulmonary disease and showing the occurrence of osseous blebs in the dorsal rib surface (inset). (Paleoart of Maurílio Oliveira). 
the rich osteocyte lacunae density, woven bone and highly vascularised tissue. In literature, the non-avian medullary bone is interpreted as not homologous with the avian medullary bone (Chinsamy \& Tumarkin-Deratzian, 2009; Cerda et al., 2014; Prondvai, 2017). Based on the observed similarities between the endosteal bone and non-avian medullary bone, we consider that such microstructural similarity between pathological and medullary bone should be taken into account, at least to future discussions of its occurrence in the rib cage of dinosaurs.

\section{CONCLUSIONS}

We infer that both dorsal and cervical ribs, which were assigned to the specimen DGM 198-R, belonged to a subadult semaphoront, while the haemal arch DGM 200$\mathrm{R}$ belonged to an adult. The distinction between the bone sizes and the microstructure (associated to the inferred ontogenetic stages) indicates that the specimens DGM 198$\mathrm{R}$ and 200-R belonged to distinct organisms.

The microstructure of the cervical rib corroborates the proximodistal variation of the bone, with endochondral anterior portions and metaplastic posterior ones, with high muscular influence. The sections of the dorsal rib indicated a brief cyclical growth in this aeolosaurini titanosaur.

We identified a pneumonia intra-thoracic infection reactive bone in the dorsal rib, probably related to tuberculosis, which is the first case among non-avian dinosaurs. Such microstructure is similar to the medullary bone identified in non-avian dinosaurs. Although our results cannot discard the identification of the medullary bone among non-avian dinosaurs, it adds new data to further discussions on the pathological and medullary bones among thoracic bones of non-avian dinosaurs.

\section{ACKNOWLEDGEMENTS}

This work was supported by the CAISEP (Comisión de Ayudas a la Investigación de la Sociedad Española de Paleontología) project \#2018-07153. We thank the Laboratório de Diptera (Museu Nacional - Universidade Federal do Rio de Janeiro) for the access to their microscopy resources. We acknowledge Maurílio Oliveira by the paleoart of Figure 11. We also thank the comments of the reviewers, Bruce Rothschild (Biodiversity Institute, University of Kansas) and Emmanuel Tschopp (Centrum for Natural Sciences of University of Hamburg), which have significantly improved the final version of the manuscript. We thank Victoria Barros for reviewing the English in the manuscript drafts. The following authors want to acknowledge each one of the organisations of their research funding: Conselho Nacional de Desenvolvimento Científico e Tecnológico (CNPq, MSc fellowship \#134422/2016-3 [2016-2018 period] to ASB; PhD fellowship \#140789/2016-2 [20162020 period] to $\mathrm{BH}$; grant $\# 311715 / 2017-6$ to JMS; and grants \#420687/2016-5 and \#313461/2018-0 to AWAK); Fundação de Desenvolvimento Carlos Chagas Filho de Amparo à Pesquisa do Estado do Rio de Janeiro (FAPERJ \#E-26/202.905/2018 to AWAK), Fundação de Amparo à Pesquisa do Estado do Amazonas (FAPEAM, fellowship \# 062.00166/2020 to LGS) and Coordenação de Aperfeiçoamento de Pessoal de Nível Superior (CAPESPROANTAR, fellowship \# 88887.336584/2019-00 to ASB).

\section{DATA AVAILABILITY}

The high-resolution photomicrographs are available at Morphobank online repository: Project 3797: A. S. Brum, K. L. N. Bandeira, B. Holgado, L. G. Souza, R. V. Pêgas, J. M. Sayão, D. A. Campos, A. W. A. Kellner. 2021. Palaeohistology and palaeopathology of an Aeolosaurini (Sauropoda: Titanosauria) from Morro do Cambambe (Upper Cretaceous, Brazil). Spanish Journal of Palaeontology (2021). Access via: http://morphobank. org/permalink/?P3797.

\section{REFERENCES}

Anné, J., Garwood, R.J., Lowe, T., Withers, P.J. \& Manning, P.L. 2015. Interpreting pathologies in extant and extinct archosaurs using micro-CT. PeerJ, 3, e1130; doi: 10.7717/ peerj. 1130.

Anson, C., Rothschild, B. \& Naples, V. 2012. Soft tissue contributions to pseudopathology of ribs. Advances in Anthropology, 2, 57-63; doi: 10.4236/aa.2012.22007.

Aureliano, T., Ghilardi, A.M., Buck, P.V., Fabbri, M., Samathi, A., Delcourt, R., Fernandes, M.A. \& Sander, M. 2018. Semi-aquatic adaptations in a spinosaur from the Lower Cretaceous of Brazil. Cretaceous Research, 90, 283-295; doi: 10.1016/j.cretres.2018.04.024.

Bandeira, K.L.N., Simbras, F.M., Machado, E.B., Campos, D.D.A., Oliveira, G.R. \& Kellner, A.W.A. 2016. A New Giant Titanosauria (Dinosauria: Sauropoda ) from the Late Cretaceous Bauru Group. PLoS One, 11(10), e0163373; doi: 10.1371/journal.pone.0163373.

Bandeira, K.L.N., Machado, E.B., Campos, D.A. \& Kellner, A.W.A. 2019. New Titanosaur (Sauropoda, Dinosauria) records from the Morro do Cambambe Unit (Upper Cretaceous), Mato Grosso State, Brazil. Cretaceous Research, 103, 104155; doi: 10.1016/j.cretres.2019.06.001. 
Barbosa, F.H.S., Pereira, P.V.L.G.C., Bergqvist, L.P. \& Rothschild, B.M. 2016. Multiple neoplasms in a single sauropod dinosaur from the Upper Cretaceous of Brazil. Cretaceous Research, 62, 13-17; doi: 10.1016/j. cretres.2016.01.010.

Barbosa, F.H.S., Ribeiro, I.C., Pereira, P.V.L.G.C. \& Bergqvist, L.P. 2018. Vertebral lesions in a titanosaurian dinosaur from the Early-Late Cretaceous of Brazil. Geobios, 51, 385-389; doi: 10.1016/j.geobios.2018.08.002.

Barbosa, F.H.S., Marinho, T.S., Iori, F.V. \& Paschoa, L.S. 2019. A case of infection in na Aeolosaurini (Sauropoda) dinosaur from the Upper Cretaceous of São Paulo, southeastern Brazil, and the impact on its life. Cretaceous Research, 96, 1-5; doi: 10.1016/j.cretres.2018.12.004.

Bell, D.J. \& Campbell, J.G. 1961. Pathological and biochemical observations on virus-induced osteopetrosis gallinarum. Journal of Comparative Pathology and Therapeutics, 71, 85-93; doi: 10.1016/S03681742(61)80011-8.

Brusatte, S.L., Candeiro, C.R.A. \& Simbras, F.M. 2017. The last dinosaurs of Brazil: the Bauru Group and its implications for the end-Cretaceous mass extinction. Anais da Academia Brasileira de Ciências, 89, 14651485; doi: 10.1590/0001-3765201720160918.

Calvo, J.O. \& González Riga, B. 2019. Baalsaurus mansillai gen. et sp. nov. a new titanosaurian sauropod (Late Cretaceous) from Neuquén, Patagonia, Argentina. Anais da Academia Brasileira de Ciências, 91(Suppl. 2), e20180061; doi: 10.1590/0001-3765201820180661 Canoville, A., Schweitzer, M.H. \& Zanno, L.E. 2019. Systemic distribution of medullary bone in the avian skeleton: ground truthing criteria for the identification of reproductive tissues in extinct Avemetatarsalia. BMC Evolutionary Biology, 19, 1-20; doi: 10.1186/s12862019-1402-7.

Carballido J.L., Pol D., Otero A., Cerda I.A., Salgado L., Garrido A. C., Ramezani J., Cúneo N.R. \& Krause J.M. 2017. A new giant titanosaur sheds light on body mass evolution among sauropod dinosaurs. Proceedings of the Royal Society B, 284, 20171219; doi: 10.1098/ rspb.2017.1219.

Castenet, J., Curry Rogers, K., Cubo, J. \& Boisard, J.J. 2000. Periosteal bone growth rates in extant ratites (ostriche and emu). Comptes Rendus de l'Academie des Sciences, Serie III, Sciences de la Vie, 323, 543-550; doi: 10.1016/ s0764-4469(00)00181-5.

Cerda, I.A., Chinsamy, A. \& Pol, D. 2014. Unusual endosteally formed bone tissue in a patagonian basal sauropodomorph dinosaur. The Anatomical Record, 297, 1385-1391; doi: 10.1002/ar.22954.

Chinsamy, A. \& Raath, M. A. 1992. Preparation of fossil bone for histological examination. Palaeontologia Africana, 29, 39-44.

Chinsamy, A. \& Tumarkin-Deratzian, A. 2009. Pathologic bone tissues in a turkey vulture and a nonavian dinosaur: implications for interpreting endosteal bone and radial fibrolamellar bone in fossil dinosaurs. The Anatomical Record, 292, 1478-1484; doi: 10.1002/ar.20991.
Chinsamy-Turan, A. 2005. The Microstructure of Dinosaurs Bone: Deciphering Biology with Fine Scale Techniques. The Johns Hopkins University Press, Maryland.

Christian, A. \& Dzemski, G. 2007. Reconstruction of the cervical skeleton posture of Brachiosaurus brancai Janensch, 1914 by an analysis of the intervertebral stress along the neck and a comparison with the results of different approaches. Fossil Record, 10, 38-49; doi: 10.1002/mmng.200600017.

Converse, K.A. 2007. Avian tuberculosis. In: Infectious Diseases of Wild Birds (eds. Thomas, N.J., Hunter, D.B. \& Atkinson, C.T.). Blackwell Publishing, Ames, Iowa, 289-302.

de Margerie, E. 2004. Assessing a relationship between bone microstructure and growth rate: a fluorescent labelling study in the king penguin chick (Aptenodytes patagonicus). Journal of Experimental Biology, 207, 869-879; doi: 10.1242/jeb.00841.

de Margerie, E., Cubo, J. \& Castanet, J. 2002. Bone typology and growth rate: testing and quantifying 'Amprino's rule' in the mallard (Anas platyrhynchos). Comptes Rendus Biologies, 325, 221-230; doi: 10.1016/S16310691(02)01429-4.

Erickson, G.M. \& Tumanova, T.A. 2000. Growth curve of Psittacosaurus mongoliensis Osborn (Ceratopsia: Psittacosauridae) inferred from long bone histology. Zoological Journal of the Linnean Society, 130, 551-566; doi: 10.1006/zjls.2000.0243.

Francillon-Vieillot, H., de Buffrénil, V., Castenet, J., Geraudie, J., Meunier, F.J., Sire, J.-Y., Zylberberg, I. \& de Ricqlès, A. 1990. Microstructure and mineralization of vertebrate skeletal tissues. In: Skeletal Biomineralization Patterns, Processes and Evolutionary Trends (ed. Carter, J.G.). Van Nostrand Reinhold Company, New York, 471-548.

Franco-Rosas, A.C., Salgado, L., Rosas, C.F. \& Carvalho, I.S. 2004. Nuevos materiales de titanosaurios (Sauropoda) en el Cretácico Superior de Mato Grosso, Brasil. Revista Brasileira de Paleontologia, 7, 329-336; doi: 10.4072/ rbp.2004.3.04

Frank, R.M.I. \& Franklin, R.M. 1982. Electron microscopy of avian osteopetrosis induced by retrovirus MAV.2-O. Calcified Tissue International, 34, 382-390; doi: 0171967X/82/0034-0382.

Gallina, P.A. 2012. Histología ósea del titanosaurio Bonitasaura salgadoi (Dinosauria: Sauropoda) del Cretácico Superior de Patagonia. Ameghiniana, 49, 289-302; doi: 10.5710/AMGH.v49i3(519).

Gilmore, C.W. 1936. Osteology of Apatosaurus, with special reference to specimens in the Carnegie Museum. Memoirs of the Carnegie Museum, 11, 175-300.

Gonzalez, R., Gallina, P.A. \& Cerda, I.A. 2017. Multiple paleopathologies in the dinosaur Bonitasaura salgadoi (Sauropoda: Titanosauria) from the Upper Cretaceous of Patagonia, Argentina. Cretaceous Research, 79, 159-170; doi: 10.1016/j.cretres.2017.07.013.

González Riga, B.J., Mannion, P.D., Poropat, S.F., Ortiz David, L. \& Coria, J.P. 2018. Osteology of the Late Cretaceous Argentinean sauropod dinosaur Mendozasaurus 
neguyelap: implications for basal titanosaur relationships. Zoological Journal of the Linnean Society, 184, 136-181; doi:10.1093/zoolinnean/zlx103.

González Riga, B.J.G., Lamanna, M.C., Otero, A., David, L.D.O, Kellner, A.W.A. \& Ibiricu, L.M. 2019. An overview of the appendicular skeletal anatomy of South American titanosaurian sauropods, with definition of a newly recongnized clade. Anais da Academia Brasileira de Ciências, 91(Suppl. 2), e20180374; doi: 10.1590/00013765201920180374.

Hatcher, J.B. 1901. Diplodocus Marsh, its osteology, taxonomy and probable habits, with a restoration of the skeleton. Memoirs of the Carnegie Museum, 1, 1-64.

Holmes, J.R. 1961. Radiological changes in avian osteopetrosis. British Journal of Radiology, 34, 368-377.

Horner, J.R., Padian, K. \& de Riqclès, A. 2001. Comparative osteohistology of some embryonic and perinatal archosaurs: developmental and behavioral implications for dinosaurs. Paleobiology, 27, 39-58; doi: 10.1666/0094-8373(2001)027<0039:COOSEA>2.0.CO;2.

Hübner, T.R. 2012. Bone histology in Dysalotosaurus lettowvorbecki (Ornithischia: Iguanodontia) - variation, growth, and implications. PLoS One, 7, e29958. doi: 10.1371/journal.pone.0029958.

Hurum, J.H., Bergan, M., Müller, R., Nystuen, J.P. \& Klein, N. 2006. A Late Triassic dinosaur bone, offshore Norway. Norwegian Journal of Geology, 117, 117-123.

Kellner, A.W.A. \& de Azevedo, S.A.K. 1999. A new sauropod dinosaur (Titanosauria) from the Late Cretaceous of Brazil. In: Proceedings of the Second Gondwanan Dinosaur Symposium (eds. Tomida, Y., Rich, T.H. \& Vickers-Rich, P.). National Science Museum Monographs, 15, 111-142.

Kellner, A.W.A., Campos, D.A., Sayão, J.M., Saraiva, A.A.E., Rodrigues, T., Oliveira, G., Cruz, L., Costa, F.R., Silva, H. \& Ferreira, J.S. 2013. The largest flying reptile from Gondwana: a new specimen of Tropeognathus cf. T. mesembrinus Wellnhofer, 1987 (Pterodactyloidea, Anhangueridae) and other large pterosaurs from the Romualdo Formation, Lower Cretaceous, Brazil. Anais da Academia Brasileira de Ciências, 85(1), 113-135. doi: 10.1590/S0001-37652013000100009

Kellner, A.W.A., Rodrigues, T., Costa, F.R., Weinschütz, L.C., Figueiredo, R.G., Souza, G.A., Brum, A.S., Eleutério, L., Mueller, C.W. \& Sayão, J.M. 2019. Pterodactyloid pterosaur bones from Cretaceous deposits of the Antarctic Peninsula. Anais da Academia Brasileira de Ciências, 91(Suppl. 2), e20191300. doi: 10.1590/0001-3765201920191300

Kirev, T.T. 1984. Characterisation of osteopetrosis induced by virus strain Pts 56 in guinea fowl. Avian Pathology, 13, 647-656; doi: 10.1080/03079458408418563.

Klein, N. 2004. Bone histology and growth of the prosauropod dinosaur Plateosaurus engelhardti Meyer, 1837 from the Norian bonebeds of Trossingen (Germany) and Frick (Switzerland). PhD. Thesis, Universität Bonn (unpublished).

Klein, N. \& Sander, P.M. 2007. Bone histology and growth of the prosauropod dinosaur Plateosaurus engelhardti von Meyer, 1837 from the Norian bonebeds of Trossingen (Germany) and Frick (Switzerland). In: Evolution and
Palaeobiology of Early Sauropodomorph Dinosaurs (eds. Barrett, P.M. \& Batten, D.J.). Blackwell Publishing, Oxford. Special Papers in Palaeontology, 77, 169-206.

Klein, N., Christian, A. \& Sander, P.M. 2012. Histology shows that elongated neck ribs in sauropod dinosaurs are ossified tendons. Biology Letters, 8, 1032-1035; doi: 10.1098/rsbl.2012.0778.

Lambertz, M., Bertozzo, F. \& Sander, P.M. 2018. Bone histological correlates for air sacs and their implications for understanding the origin of the dinosaurian respiratory system. Biology Letters, 14, 20170514; doi: 10.1098/ rsbl.2017.0514.

Lamm, E.-T. 2013. Bone histology of fossil tetrapods. In: Preparation and Sectioning of Specimens (eds. Padian, K. \& Lamm, E.-T.). University of California Press, $55-160$.

Lee, A.H. \& Werning, S. 2008. Sexual maturity in growing dinosaurs does not fit reptilian growth models. Proceedings of the National Academy of Sciences, 105, 582-587; doi: 10.1073/pnas.0708903105.

Mitchell, J. \& Sander, P.M. 2014. The three-front model: A developmental explanation of long bone diaphyseal histology of Sauropoda. Biological Journal of the Linnean Society, 112, 765-781; doi: 10.1111/bij.12324.

Mitchell, J., Sander, P.M. \& Stein, K. 2017. Can secondary osteons be used as ontogenetic indicators in sauropods? Extending the histological ontogenetic stages into senescence. Paleobiology, 43, 321-342; doi: 10.1017/ pab.2016.47.

Mitchell, M.A. 2012. Mycobacterial infections in reptiles. Veterinary Clinics of North America: Exotic Animal Practice, 15, 101-111; doi: 10.1016/j.cvex.2011.10.002.

Naples, V.L. \& Rothschild, B.M. 2011. Do ribs actually have a bare area? A new analysis. HOMO: Journal of Comparative Human Biology, 62, 368-373; doi: 10.1016/j.jchb.2011.08.001.

O'Leary, M.A. \& Kaufman, S.G. 2012. Morphobank 3.0: web application for morphological phylogenetics and taxonomy. Avaiable at http://www.morphobank.org.

Organ, C.L. \& Adams, J. 2005. The histology of ossified tendon in dinosaurs. Journal of Vertebrate Paleontology, 25, 602-613; doi: 10.1671/0272-4634(2005)025[0602:TH OOTI]2.0.CO;2.

Padian, K., de Ricqlès, A. \& Horner, J.R. 2001. Dinosaurian growth rates and bird origins. Nature, 412, 405-408; doi: $10.1038 / 35086500$.

Padian, M.A., Werning, S. \& Horner, J.R. 2016. A hypothesiss of differential secondary bone formation in dinosaurs. Comptes Rendus Palevol, 15, 40-48; doi: 10.1016/j.crpv.2015.03.002 1631-0683/O.

Prondvai, E. 2017. Medullary bone in fossils: function, evolution and significance in growth curve reconstructions of extinct vertebrates. Journal of Evolutionary Biology, 30, 440-460; doi: 10.1111/jeb.13019.

Prondvai, E. \& Stein, K.H.W. 2014. Medullary bone-like tissue in the mandibular symphyses of a pterosaur suggests non-reproductive significance. Scientific Reports, 4, 1-9; doi: 10.1038/srep06253. 
Prondvai, E., Stein, K.H.W., Ricqlès, A.D.E. \& Cubo, J. 2014. Development-based revision of bone tissue classification: the importance of semantics for science. Biological Journal of the Linnean Society, 112, 799-816; doi: 10.1111/bij.12323.

Reid, R.E.H. 1997. Histology of bone and teeths. In: Encyclopedia of Dinosaurs (eds. Currie, P.J. \& Padian, K.). Academic Press, San Diego, 329-339.

Rothschild, B.M. \& Berman, D.S. 1991. Fusion of caudal vertebrae in Late Jurassic sauropods. Journal of Vertebrate Paleontology, 11, 29-36; doi: 10.1080/02724634.1991.10011373.

Schweitzer, M.H., Horner, J.R., Wittmeyer, J.L. \& Horner, J.R. 2005. Gender-specific reproductive tissue in ratites and Tyrannosaurus rex. Science, 308, 1456-1460; doi: 10.1126/science. 1112158 .

Schweitzer, M.H., Zheng, W., Zanno, L., Werning, S. \& Sugiyama, T. 2016. Chemistry supports the identification of gender-specific reproductive tissue in Tyrannosaurus rex. Scientific Reports, 6, 1-10; doi: 10.1038/srep23099.

Starck, J.M. \& Chinsamy, A. 2002. Bone microstructure and developmental plasticity in birds and other dinosaurs. Journal of Morphology, 254, 232-246; doi: 10.1002/ jmor. 10029.

Surmik, D., Szczygielski, T., Katarzyna, J. \& Rothschild, B.M. 2018. Tuberculosis-like respiratory infection in 245-million-year-old marine reptile suggested by bone pathologies. Royal Society Open Science, 5, 180225; doi: 10.1098/rsos. 180225 .

Tschopp, E., Wings, O., Frauenfelder, T. \& Rothschild, B.M. 2016. Pathological phalanges in a camarasaurid sauropod dinosaur and implications on behaviour. Acta Palaeontologica Polonica, 61, 125-134; doi: 10.4202/ app.00119.2014.

Waskow, K. \& Mateus, O. 2017. Dorsal rib histology of dinosaurs and a crocodile from western Portugal: Skeletochronological implications on age determination and life history traits. Comptes Rendus Palevol, 16, 425-439; doi: 10.1016/j.crpv.2017.01.003.

Waskow, K. \& Sander, P.M. 2014. Growth record and histological variation in the dorsal ribs of Camarasaurus sp. (Sauropoda). Journal of Vertebrate Paleontology, 34, 852-869; doi: 10.1080/02724634.2014.840645.

Wedel, M. \& Sanders, R.K. 2002. Osteological correlates of cervical musculature in Aves and Sauropoda (Dinosauria, Saurischia), with comments on the cervical ribs of Apatosaurus. PaleoBios, 22, 1-6.

Weska, R.K. 2006. Uma síntese do Cretáceo Superior matogrossense. Revista Geociências, 25, 71-81.

Woodruff, D.C., Fowler, D.W. \& Horner, J.R. 2017. A new multi-faceted framework for deciphering diplodocid ontogeny. Palaeontologia Electronica, 20.3.43A, 1-53; doi: $10.26879 / 674$. 
